\title{
HOW TO POVERTY AND CONTRIBUTIONS FOR TOURISM IN WEST SUMATRA
}

\author{
Mike Triani \\ Department of Economics, Faculty of Economics, Universitas Negeri Padang \\ Jl. Prof. Dr. Hamka Air Tawar Padang \\ E-mail : miketriani@fe.unp.ac.id
}

diterima: 25/6/2019; direvisi: 17/9/2019; diterbitkan: 24/9/2019

\begin{abstract}
How the Influence the tourism sector contributes to poverty in the province of West Sumatra. The data used is secondary data from the combination of time series and cross section from 2015 to 2017, with documentation from collection institutions and agencies. The research methods used are: (1) Fixed Effect Analysis (FEM), (2) Classical Assumption Test . The regional income from the tourism sector contributes to the reduction of poverty in the province of West Sumatra but is not significant. (2) The number of hotels in the province of West Sumatra. (3) Micro small and medium enterprises contributing to the poverty reduction in the province of West Sumatra but is not significant. (4) The regional revenue of the tourism sector, the number of hotel rooms, and the micro and small enterprises together has a significant contribution to poverty in the province of West Sumatra.
\end{abstract}

Keywords: The revenue of tourism sector, Number of micro rooms, enterprises, Poverty, and Fixed Effext Model (FEM)

\section{BACKGROUND}

Poverty is one of the problems faced by various countries in the world, including Indonesia which has been faced with poverty problems from year to year. Many policies have been issued by the government to reduce poverty in Indonesia, but the goal of the policy is still not fully achieved. There are still many people in Indonesia who live below the poverty line. Of course this is a challenge for the government to complete it, not only the central government but the regional government must also work hand in hand in alleviating poverty in their respective regions. Based on Law No. 24 of 2004 poverty is a socio-economic condition of a person or group of people whose basic rights are not fulfilled to develop and maintain a dignified life.

West Sumatra Province is one of the ten provinces that have the lowest number of poor people in Indonesia, where in mid 2017 West Sumatra became one of the 10 provinces that had the lowest number of poor people in Indonesia, namely $6.5 \%$. Of course this reduction in poverty is a result of the integration of various economic sectors that work together to reduce poverty in the Province of West Sumatra. One sector in West Sumatra which is the leading sector is the tourism sector. In addition, the small and medium micro business sector also has a direct and indirect contribution in reducing poverty.

At present a lot of development is being carried out in the tourism sector, especially in West Sumatra, because West Sumatra is one of the provinces given the diversity of natural resources that exist, both in terms of land, sea, and culture. This is what makes the tourism sector one of the leading sectors. Because the development of the tourism sector not only contributes to the sector itself but also contributes to the surrounding community. One of the expected contributions from the tourism sector is as a way of alleviating poverty in the community, because with the increase in 
Jurnal Ilmiah Ekonomi dan Bísnis

Vol. 16. No.2, September 2019: 183-190

EISSN : $2442-9813$

ISSN : $1829-9822$

the tourism sector it will indirectly reduce the poverty of existing communities, both through absorbed labor, small and medium microenterprises. SMEs, namely through the pathways directly and indirectly, which creates a multiplier effect(multiplier).Direct paths as the existence of MSMEs has a positive impact on reducing the number of poor people is the amount of employment opportunities created by MSMEs themselves (Tambunan, 2012).

At present the income received from the tourism sector / tourism sector PAD from the last three years, namely from 2015-2017 has always increased every year. This increase was also accompanied by the increase of hotels in West Sumatra Province. Hotels and Tourism are two things that cannot be separated from each other. Both of these sectors influence each other. And as with the tourism sector, hotels have also increased over the past three years, this can be seen from the number of hotel rooms that have also increased.

In addition to the original regional income and the number of hotel rooms, the other variables examined in this study are small and medium micro enterprises which are calculated based on the number of small and medium micro enterprises in the Regency / City in West Sumatra Province. Over the past three years, from 2015-2017 the number of MSMEs has also increased every year.

\section{LITERATURE REVIEW}

Poverty

Based on Law No. 24 of 2004, poverty is a socio-economic condition of a person or group of people whosenot basic rights arefulfilled to maintain and develop a dignified life. Basic needs that are the rights of a person or group of people include food needs, health, education, employment, housing, clean water, land, natural resources, the environment, a sense of security from treatment or threats of violence, and the right to participate in the implementation of social life and politics The

level of poverty in a country depends on two main factors, namely: (1) the level of average national income, and (2) the width of the gap in income distribution (Todaro, 2006). This means that if a country has a high average national income, and the income distribution gap is high, this country will not be able to get out of poverty.

The cause of poverty is seen from the economic side. First, on a micro level, poverty arises because of the inequality of patterns of resource ownership that lead to an unequal income distribution. The poor have only limited resources and low quality. Second, poverty arises from differences in the quality of human resources. Low quality of human resources means low productivity, which in turn low wages. The low quality of human resources is due to low education, the fate of disadvantaged people, discrimination, or because of offspring. Third, poverty arises from differences in access in capital (Kuncoro, 2003)

\section{Tourism Sector}

The meaning of the word tourism refers to the word tourism which comes from Latin tornare and Greek tornos which means to rotate; movement around the center. While the word tourism itself, which is modern English, means a process of behavior of people who travel from one point to another and return to their original point (Theobald in Mill, 2000).

According to the WTO Tourism is the activity of people who travel and live in places outside their usual environment for no more than one consecutive year for holidays, business, and other purposes. In a study conducted (ILO, 2011: 138 p) the tourism sector has a contribution to reducing poverty in a region. 
Tourism contributes to the collection of foreign currency (foreign exchange), increasing income and employment, can improve the structure of the economy and encourage the development of small businesses (Mill, 2000).

Micro, Small and Medium Enterprises (MSMEs)

According to Law number 20 of 2008 concerning Micro, Small and Medium Enterprises, MSMEs are defined as follows: 1. Micro-enterprises are productive businesses owned by individuals and / or individual business entities that meet the criteria of MicroBusiness as stipulated in this Act. 2. Small Business is a productive economic enterprise that is independent, carried out by individuals or business entities that are not subsidiaries or not branches of companies that are owned, controlled, or become part of either directly or indirectly from Medium or Large Businesses that fulfill criteria for Small Business as referred to in this Law. 3. Medium Enterprises are productive economic businesses that are independent, carried out by individuals or business entities that are not subsidiaries or branches of companies that are owned, controlled, or become part of either directly or indirectly 7 directly with Small or Large Businesses with a number of net assets or annual sales proceeds as stipulated in the Act.

According to (Tambunan, 2012) the relationship between the existence of MSEs and poverty in an area can be "positive" or "negative". Positive in terms of the existence of MSEs because there is poverty. This can be explained as follows. In general everywhere, a company arises because there is market attractiveness, bothmarkets output (opportunities to sell products) andmarkets input (opportunities to get input for production). This relationship also applies to the growth of MSMEs. However, in many developing / poor countries, the existence of output markets and markets input that make the number of MSMEs grow rapidly is closely related to poverty.

\section{RESEARCH METHODS}

Contribution of Tourism Sector to Poverty in West Sumatra Province.

The data used in this study are panel data, which is a combination ofdata time series and cross section from the period 2015 to 2017. The variables used in this study are Regional Revenue of Tourism Sector (X1), number of hotel rooms (X2), MSMEs (X3) and poverty (Y).

The models used in this study are:

$\log Y_{i t}=\beta_{0}+\beta_{1} \log X_{1 i t}+\beta_{2} \log X_{2 i t}+$ $\beta_{3} \log X_{3 i t}+u_{i t}$

Where: $\mathrm{Y}$ is poverty, $X_{1}$ is Regional Revenue of Tourism Sector, $X_{2}$ is the number of hotel rooms, $X_{3}$ is MSME, $\mathrm{u}$ is error term and $\alpha, \beta_{1,2,3,4,5}$ are regression coefficients.

Operational Definition

Table 1 Contribution of the Tourism Sector to Poverty in the Province of West Sumatra

Variable Definition

$\begin{array}{ll}\text { Regional } & \begin{array}{l}\text { Original revenue derived } \\ \text { purely from tourism sector } \\ \text { Revenue Of } \\ \text { Tourism }\end{array} \\ \text { rectorenues. The data taken in } \\ \text { this study is the PAD of the } \\ \text { tourism sub-sector with a } \\ \text { size of billions of rupiah } \\ \text { units by Regency / City in } \\ \text { West Sumatra Province } \\ \text { from 2015-2017. }\end{array}$


Jurnal Ilmiah Ekonomi dan Bisnis

Vol. 16. No.2, September 2019: 183-190

EISSN : 2442 - 9813

ISSN : 1829-9822

Number Of by the hotel to be offered to

Hotel Room visitors. Data on the number of hotel rooms with the size of this unit are calculated according to the District / City in West Sumatra Province from 2015-2017.

MSMEs

Productive economic businesses that are independent, carried out by individuals or business entities that are not subsidiaries or not branches of companies that are owned, controlled, or become part of either directly or indirectly. Data is calculated in units per Regency / City in the Province of West Sumatra in 2015-2017.

Poverty inability of an individual to fulfill the basic needs of his life. The data taken in this study is the number of poor people with a size of thousand units according to Regency / City in West Sumatra Province from 2015-2017.
Test, Fixed Effect Model Test, t Test and the last Test $F$. The results of the study can be seen in Table 2.

Table 2. Estimated Results with Fixed

$$
\text { Effect Model }
$$

Dependent Variable: LOG (Y)

Method: Panel Least Squares

Date: 03/14/19 Time: 17:54

Sample: 20152017

Periods included: 3

Cross-sections included: 19

Total panels (balanced) observations: 57

\begin{tabular}{lllll}
\hline & $\begin{array}{l}\text { Coeffici } \\
\text { ent }\end{array}$ & Std. Error & t-Statistic & Prob. \\
\hline & - & & & \\
& 0.04036 & & - & \\
LOG (X1) & 8 & 0.032750 & 1.232621 & 0.2259 \\
& - & & & \\
LOG (X2) & 0.32631 & & - & \\
& 5 & 0.088024 & 3.707113 & 0.0007 \\
LOG (X3) & - & & & \\
C & 2.13068 & & - & \\
& 5.83209 & 0.159592 & 0.818853 & 0.4184 \\
& 1 & 1.500346 & 3.887165 & 0.0004 \\
\hline
\end{tabular}

Effects Specification

Cross-section fixed (dummy variables)

\begin{tabular}{llll}
\hline & 0.92820 & & \\
& 4 & Mean dependent var & $\begin{array}{l}1.8635 \\
\text { R-squared }\end{array}$ \\
$\begin{array}{l}\text { Adjusted R- } \\
\text { squared }\end{array}$ & 0.88512 & & 0.3767 \\
& 6 & SD dependent var & 67 \\
& & & - \\
SE of regression & 0.12769 & & 0.9940 \\
& 8 & Akaike info criterion & 67 \\
& 0.57073 & & - \\
Sum squared resid & 9 & Schwarz criterion & 0.2055 \\
& & & - \\
& 50.3309 & & 0.6876 \\
Log likelihood & 2 & Hannan-Quinn criter. & 12 \\
& 21.5471 & & 2.3545 \\
F-statistic & 1 & Durbin-Watson stat & 44 \\
& 0.00000 & & \\
Prob (F-statistic) & 0 & &
\end{tabular}

Source: Olah Data Eviews 9 
In Table 2 above shows the estimation of the contribution of the tourism sector to poverty in West Sumatra Province as follows:

$$
\begin{aligned}
& \log Y_{t}= \\
& 5.8320-0,0403 \log X_{1}- \\
& 0,3263 \log X_{2}-0,1307 \log X_{3}
\end{aligned}
$$

The form of the influence Regional Revenue of Tourism Sector (X1) on poverty in the Regency / City in West Sumatra Province $(\mathrm{Y})$ is negative, with the regression cointegration coefficient of 0.0403 percent. Where in this case means that if the tourism sector PAD increases by one percent then poverty will decrease by 0.0403 percent. This means that the higher the PAD in the tourism sector, the poverty will tend to decline in the districts I cities in West Sumatera Province assuming ceteris paribus.

the number of hotel rooms (X2) has a negative influence on poverty in regencies I cities in West Sumatra Province with a regression coefficient of -0.33263 percent. This means that every increase of one percent of the number of hotel rooms will cause a decrease in poverty of 0.3263 percent with the assumption of ceteris paribus. Furthermore the form of variable influence on the number of MSMEs (X3) on poverty in the Regency / City in West Sumatra Province is positive with the regression coefficient -0, 1307 percent. This means that when the number of MSMEs increases by one percent, poverty will decrease by $0.1307 \%$. Assuming ceteris paribus.

Based on table 2, it can be seen that the constant value obtained is 5.83 percent. This means that Regional Revenue of Tourism Sector (X1), the number of hotel rooms (X2), and the number of MSMEs (X3) are fixed, then poverty is 5.83 percent. The three variables in the study have contributed to the reduction of poverty in districts / cities in West Sumatra Province.
Contribution of Regional Revenue of Tourism Sector to Poverty in West Sumatra Province

Based on data processing and hypothesis testing, it was stated that the Regional Revenue of Tourism Sector has a significant but not significant contribution to poverty in regencies / cities in West Sumatra Province. Based on data processing carried out when there was a one percent increase in Regional Revenue of Tourism Sector would reduce poverty by 0.0403 percent. Tourism sector PAD (X1) has a contribution to poverty reduction except that the contribution provided is not significant. Of course this figure is still very small if seen from the potential of the West Sumatra tourism sector which is very large should be able to provide a significant contribution to poverty. This can be caused by the management of the tourism sector in the regencies / cities in West Sumatra Province which is still not optimal and not evenly distributed, and there is still a lot of untouched tourism potential in several regencies / cities. In addition, the utilization of income received from a region from the tourism sector or the Regional Revenue of Tourism Sector is still not used optimally, which should be received for re-use of income received for repairs, renewal, addition of tourism facilities. Besides this, this can also be caused by the weak integration between economic sectors, in this case the tourism sector which still cannot be utilized by other economic sectors in the context of reducing poverty in regencies / cities in West Sumatra Province.

The results of this study are in line with the research conducted by Mbaiwa (2005) with the research title "Enclave tourism and its socio-economic impacts in the Okavango Delta, Botswana". Where the results of his research say that the tourism sector has not been able to contribute significantly to rural economic 
Jurnal Ilmiah Ekonomi dan Bisnis

Vol. 16. No.2, September 2019: 183-190

EISSN : $2442-9813$

ISSN : $1829-9822$

development and poverty alleviation that occurs in most of the Okvango region. Based on some relevant research, it can be seen the causes of the insignificant contribution of the Regional Revenue of Tourism Sector to poverty reduction, one of which is the development of the tourism sector which only benefits urban communities investment and income derived from this sector can only be used by the urban poor but not with people in rural areas. Besides that, another factor that causes insignificant contribution given by the Regional Revenue of Tourism Sector to poverty is that investment investment in the tourism sector is dominated by the outside community while the local community only works inposition and income a low.

The results of this study are not in line with the research proposed by Dody Harris Darmawan , Adi Yunanto (2016) with the title of research on Tourism Opportunities in Reducing Poverty in the MEA Era where the results of his research concluded that the tourism sector has a role in reducing poverty, where when the tourism sector increases one percent poverty will decrease by 0.085 percent.

Contribution of Number of Hotel Rooms to Poverty in West Sumatra Province

Based on data processing and hypothesis testing, it was stated that the number of hotel rooms has a significant contribution to poverty in regencies / cities in West Sumatra Province. Based on data processing, a one percent increase in the number of hotel rooms will reduce poverty by 0.3262 percent. Here it can be indicated that the number of hotel rooms is one that reduces poverty in the Province of West Sumatra. So this can be said if the higher or more the number of hotel rooms, the poverty will decrease. Conversely, if the number of hotel rooms decreases, poverty will increase. This can be due to the number of hotel rooms that are directly proportional to the visits of visiting tourists, meaning that when tourists increase, the hospitality industry will also experience improvements in terms of hotel room services provided. That way the income will also increase, and indirectly the labor needed will also increase, unemployment decreases so that poverty will also decrease.

This is in line with the research conducted by Murohman et al (2014), in which his research entitled the role of the economic sector in poverty alleviation in West Kalimantan where the hotel sector was one of the sectors studied with the results that the hotel sector had a positive and significant effect on poverty reduction poverty. In an article published by the International Tourism Partnership it was said that the hotel sector has the ability and reasons to help reduce poverty and create economic opportunities for the most disadvantaged members of society where they operate and assume that local people will benefit from the "'" effect.trickledowndown"from its contribution to gross national product and the jobs it creates. Hospitality business people realize that they can play a much more direct role in reducing poverty.

Contribution of MSMEs to Poverty in West Sumatra Province

Based on data processing and hypothesis testing, it was stated that the number of MSMEs had a significant but not significant contribution to poverty in regencies / cities in West Sumatra Province. Based on data processing carried out when a one percent increase in the number of MSMEs will reduce poverty by 0.1306 percent.

In line with the research conducted (Tambunan, 2012) it is said that MSMEs have positive and negative influences on poverty. The hypothesis is as follows: the more unemployment or more workers with low wages, the more poverty, the more the number of MSMEs both as the only source of income (for poor people because of 
unemployment) or as a source of additional income (for people poor people because the main source of income is insufficient). But the results of this study are not in line with the research conducted by Ali, Sharafat et al (2014) entitled " The Role of Small and Medium Enterprise and Poverty in Pakistan" The results of this study confirm that micro-enterprises small and medium-sized enterprises have a strong and negative impact on poverty levels in Pakistan, which means that when the MSME sector increases, it will reduce poverty in Pakistan.

The still insignificant contribution given by MSMEs to poverty can be caused by many things, one of which is the performance and constraints of MSMEs which vary in each Regency / City in the Province of West Sumatra. So that this causes the utilization of the MSME sector is still not optimal in helping other economic sectors, especially poverty problems that exist in West Sumatra Province.

\section{CONCLUSION}

Based on the discussion of the results of the analysis in the previous chapter, a number of conclusions can be produced as follows: 1) Varibael Regional Revenue of Tourism Sector contributes to the reduction of poverty in regencies / cities in West Sumatra Province, but this contribution is not significant with the probability value is 0.2259 which is greater than the value of $\alpha=5 \%$ with a coefficient of -0.0403 . This means that every increase in the tourism sector PAD by one percent will reduce poverty by 0.0403 percent. 2) The variable number of hotel rooms has a significant contribution to poverty in the Regency / City in West Sumatra Province which is indicated by a probability of 0,0007 which is smaller than the value of $\alpha=5 \%$ with a coefficient of $-0,3262$. This means that each increase in the number of hotel rooms by one percent will reduce poverty by 0.3262 percent. 3) Variables of micro, small and medium enterprises have a contribution but not significant to poverty in districts / cities in West Sumatra Province which is indicated by a probability of 0.4184 which is greater than the value of $\alpha=5 \%$ with a coefficient of -1306 . This means that each small and medium micro business has increased by one percent, which will reduce poverty by 0.1306 percent.

\section{REFERENCES}

Central Bureau of Statistics. 2016. National Economic Survey of the Province of West Sumatra. Padang: Central Statistics

Agency 2018 Central Bureau of Statistics in West Sumatra in Figures 20122018. Padang: National Statistics

Office of West Sumatra Provincial Tourism. 2016. Tourism Profile and Statistics Povinsi West Sumatra. Padang

ILO, 2011 Toolkit on Poverty Alleviation through the Tourism Sector. International Labor Organization

Internation Tourism Partnership. 2011. "Peru: Poverty Alleviation" http://www.greenhotelier.org/desti nations/peru-poverty-allieviation/ Accessed: 26-03-2019

Kuncoro, Mudrajad. 2011. Quantitative Methods: Theories and Applications for Business and Economics : Yogyakarta: UPP AMP YKPN.

Kuncoro, Mudrajad. 2011. Development Economics: Theory, Problems and Policies: Yogyakarta: UPP AMP YKPN Policy: 
Mbaiwa, Joseph. 2005. Enclave tourism and its socio-economic impacts in the Okavango Delta, Botswana: University of Botswan Tourism Management No. 26 (2005) pp157-172

.Murohman et al. 2014. The Role of the Economic Sector in Alleviating Poverty in West Kalimantan. Lecturer in the Department of Economics, Bogor Agricultural University

Sharafat, Ali et al. 2014. "The Role of Small and Medium Enterprise and Poverty in Pakistan" Theoritical and Applied Economics Volume XXI, No. 4 (593), p. 67-80

Tambunan, Tulus. 2012. The Role of Micro and Small Enterprises in Alleviating Poverty in Regions.TrisaktiUniversity

Todaro, Michael P, Smith, Stephen C. 2006.

Development.Erlangga Jakarta

Law No 20 of 2008 concerning Micro, Small and Medium Enterprises

Law No. 24 of 2004 concerning Poverty 